\title{
THE TRANSLATION OF INDONESIAN CONCEPTUAL METAPHORS FOUND IN THE NOVEL TARIAN BUMI INTO ENGLISH
}

\author{
I Gede Megantara \\ STIBA Saraswati Denpasar \\ e-mail: Gedemegantara@gmail.com
}

\begin{abstract}
The study concerned on the translation analysis of Indonesian conceptual metaphors found in the novel Tarian Bumi into English as found in its translation novel entitled Earth Dance. The objectives of this study were to identify and analyze the types of Indonesian conceptual metaphor and the translation strategies applied in translating them. The data were the sentences and quotations which belonged to Indonesian conceptual metaphors found in the Indonesian novel Tarian Bumi and their translation products that were found in the novel Earth Dance. This study applied the theoretical framework proposed by Lakoff and Johnson (1980) in identifying and analyzing the Indonesian conceptual metaphors. Meanwhile, in revealing the translation strategies used by the translator of the novel, the study applied the theoretical framework proposed by Larson (1998). Based on observation, this study revealed that Tarian Bumi consisted of 102 Indonesian conceptual metaphors in which are divided into three types; 46 data (45\%) were identified as structural metaphors, 40 data (39\%) were ontological metaphors, and $16(16 \%)$ data were orientational metaphor. Based on the investigation of translation strategy, it was found that the translator applied the strategy of translating metaphor into metaphor by 72 data found (70.6\%), metaphor into non-figurative language by 26 data found $(25.5 \%)$, and metaphor into simile by 4 data found (3.9\%).
\end{abstract}

Keywords : Translation, Conceptual Metaphor, Structural, Orientational, Ontological.

\section{INTRODUCTION}

There are many languages exist in the world, but people needs one understanding. Thus, it needs an equipment to connect the peoples which have different languages, namely translation. Translation may be defined as the replacement of textual material in one language as the source language (SL) by equivalent textual material in another language as the target language (TL) (Catford, 1965: 20). Translation nowadays has been used in many aspects of life in aim to fulfill the human needs especially in gaining the information or knowledge of many disciplines across the world. It can be also said has many contributions in the development of some necessary sectors of life, such as in medical science, education, technology, entertainment, literature, etc. Therefore, it becomes an important thing to comprehend deeply the study of translation.
The research concerned on the analysis of translation strategies applied in literature field, especially in literary work. A kind of literary work used in this research was an Indonesian novel that had been translated into English. Meanwhile, the main analysis was focused on the conceptual metaphors that occur in the source language novel. In other words, the study tried to identify the translation strategy used by the translator in translating the Indonesian conceptual metaphors into English. In addition, the analysis also tried to reveal the classification of types of conceptual metaphors found in the source novel.

\section{Research Design}

The data source was taken from two novels, namely an Indonesian novel entitled Tarian Bumi written by Oka Rusmini and its translation novel entitled Earth Dance which was translated into English by Rani Amboyo and Thomas M. Hunter. Tarian Bumi, which is 
published by PT Gramedia Pustaka Utama in 2007, is used as the references of the source text. Meanwhile, Earth Dance is used as the references of the target text.

In collecting the data, this research used observation method with some techniques, such as reading, note taking, and classifying. The data sources were read intensively to identify the conceptual metaphors found in the source text. Those conceptual metaphors were classified into each type of conceptual metaphors in accordance with the theory proposed by Lakoff and Johnson (1980). Meanwhile, the note taking technique was used in determining the translation products of those metaphors found in English version novel as references to the analysis.

The data were analyzed by using qualitative method which is verified by quantitative data. The first step was done by identifying and classifying the types of conceptual metaphors found in the source text. Secondly, the data were analyzed to find the strategies of translation using the theory proposed by Larson (1998) by comparing the
Indonesian conceptual metaphors with their translation products in English.

The data were presented by using formal and informal method. Formally, the research presented tables and charts to show the classification and total number of the types of conceptual metaphors and their translation strategies. In addition, the research also used informal method which meant the analysis was presented descriptively.

\section{FINDING}

After collecting the Indonesian conceptual metaphors in the novel Tarian Bumi, it was found that the novel consisted of three types of conceptual metaphors, namely structural metaphors, orientational metaphors, and ontological metaphors. The number of data of each type had been presented in a form of table as follows:

Table 01. Types of Indonesian Conceptual Metaphor in the Novel Tarian Bumi.

\begin{tabular}{ccccc}
\hline No & Type of Conceptual Metaphor & & Occurrence & Percent \\
\hline 1 & Structural Metaphor & 46 & & $45 \%$ \\
2 & Orientational Metaphor & 16 & & $16 \%$ \\
3 & Ontological Metaphor & 40 & $39 \%$ \\
& Total & 102 & $100 \%$ \\
\hline
\end{tabular}

Meanwhile, based on the observation on the strategy of translating conceptual metaphors, it was identified that there were three strategies applied by the translator in translating the novel; they were the strategy of translating metaphor into metaphor, metaphor into simile, and metaphor into non-figurative language. The strategy of translating metaphor into metaphor dominated the strategy by 72 data from 102 data found. The total number of translation strategy in each type of conceptual metaphors had been presented in a table as follows: 
Table 02. Strategy of Translating Indonesian Conceptual Metaphors into English

\begin{tabular}{|c|c|c|c|c|c|c|c|c|c|}
\hline \multirow[b]{2}{*}{ No } & \multirow[b]{2}{*}{$\begin{array}{l}\text { Translation } \\
\text { Strategy }\end{array}$} & \multicolumn{6}{|c|}{ Types of Conceptual Metaphor (Occurrence) } & \multirow[b]{2}{*}{ 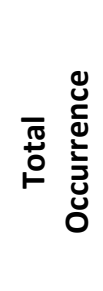 } & \multirow[b]{2}{*}{ 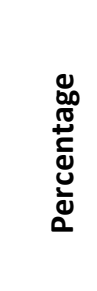 } \\
\hline & & 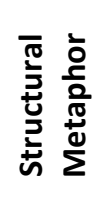 & 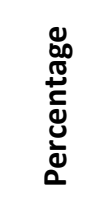 & 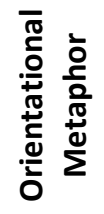 & 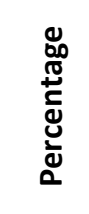 & 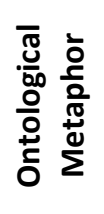 & 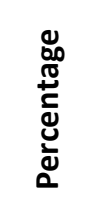 & & \\
\hline \multirow[t]{2}{*}{1} & $\begin{array}{l}\text { Metaphor into } \\
\text { Metaphor }\end{array}$ & 33 & $46 \%$ & 7 & $9.7 \%$ & 32 & $44 \%$ & 72 & $70.6 \%$ \\
\hline & Percentage & $72 \%$ & & $44 \%$ & & $80 \%$ & & & \\
\hline \multirow{2}{*}{2} & $\begin{array}{l}\text { Metaphor into } \\
\text { Simile }\end{array}$ & 4 & $100 \%$ & 0 & $0 \%$ & 0 & $0 \%$ & 4 & $3.9 \%$ \\
\hline & Percentage & $8 \%$ & & $0 \%$ & & $0 \%$ & & & \\
\hline \multirow[t]{2}{*}{3} & $\begin{array}{c}\text { Metaphor into } \\
\text { Non-figurative } \\
\text { Language }\end{array}$ & 9 & $35 \%$ & 9 & $35 \%$ & 8 & $30 \%$ & 26 & $25.5 \%$ \\
\hline & Percentage & $19 \%$ & & $56 \%$ & & $20 \%$ & & & \\
\hline & Total & 46 & & 16 & & 40 & & 102 & $100 \%$ \\
\hline & Percentage & $45 \%$ & & $16 \%$ & & $39 \%$ & & $100 \%$ & \\
\hline
\end{tabular}

\section{DISCUSSION}

\section{Strategy of Translation}

According to Larson (1980), there were three ways that could be applied by the translator in translating the metaphors; they were translating metaphor into metaphor, metaphor translated into simile, and metaphor translated into non-figurative language. After conserving the data source, it was found that the translator of the novel applied those three ways of translation strategies proposed by Larson (1998).

\section{Metaphor into Metaphor}

In this strategy, according to Larson (1998), the translator wanted to keep the image of metaphor in both of language (SL and TL). After observing the whole data, it was found that the strategy of translating metaphor into metaphor applied in three types of conceptual metaphor, namely structural, orientational, and ontological metaphor. Structural metaphor dominated this strategy by 33 data (46\%) from 72 total data found, followed by ontological metaphor by 32 data found (44\%), and orientational metaphor by 7 data found $(9.7 \%)$. The comparison of the percentage of the data occurrence in this strategy had been presented in a pie chart as follows:

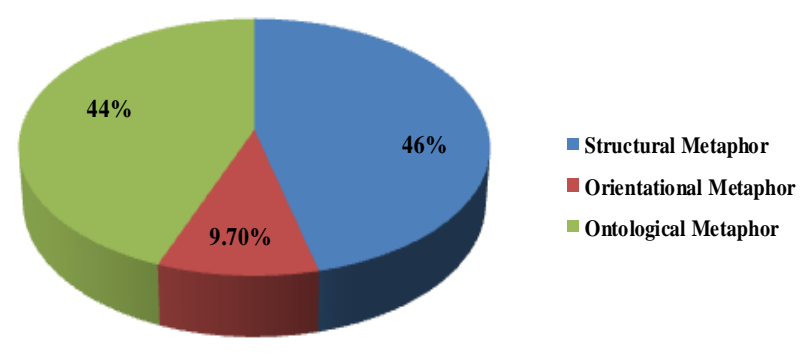

Figure 01. Percentage of the Strategy of Translating Metaphor into Metaphor in Each Type of Conceptual Metaphor 
Furthermore, the discussion of the strategy of translating metaphor into metaphor had been presented by an example as follows:

Data:

SL: Kenten tahu, keluar dari pakem memang berat.

(Tarian Bumi, p. 36, line 1)

TL: Kenten knew how difficult it was to live outside the rules.

(Earth Dance, p. 35, line 10)

Lakoff and Johnson (1980) stated that metaphor was not only reflected directly in the text, but also in our mind/ thought. It meant, there must be one idea in a text was understood in terms of another so it could be said as a metaphor. The source sentence above could be said as Indonesian conceptual metaphor (structural metaphor) which did not occur directly in the text. However, there was an idea considered led to a metaphorical concept. The word keluar has equivalence with 'go outside' in TL and the word pakem meant 'rule'. The phrase 'go outside' related to the human activity which had an association with the 'area and building'. Since human activity could not be separated with a place to stay, it was considered that the area and building were referred to the term 'house'. Based on the theoretical framework of metaphor's elements stated by Larson (1998), the term 'rule' could be said as the topic and the term 'house' was the image. Hence, it could be identified that the sentence conceptualized the metaphor 'rule is house'. The point of similarity of this metaphor could be seen from the characteristics of 'rule' and 'house' which was different in every area. Since the rule was made by the people in a particular area, it must be obeyed by the people in that area too. Likewise, when the people lived in a house, they must act in accordance with the condition or situation of that house.

Meanwhile, the translation product (TL) also had a same concept with the SL. The idea keluar dari pakem (SL) was translated into 'live outside the rule' in TL which was considered had an equivalent meaning. Therefore, related to the theory of translation strategies proposed by Larson (1998), it could be said that the translator applied the strategy of translating metaphor into metaphor since the metaphor in SL was translated literally into metaphor in TL.

\section{Metaphor into Simile}

Another strategy that could be applied by the translator in translating the metaphors based on the theory stated by Larson (1998) was by substituting them into a simile. Simile was a type of figurative language that had a similar characteristic with a metaphor which had an additional words 'as' or 'like'. Having done the observation, it was revealed that this strategy was only applied in one type of conceptual metaphor, namely structural metaphor by 4 total data found. Furthermore, the discussions of the strategy of translating metaphor into simile had been presented by an example as follows:

Data:

SL: Hidup bagiku adalah pertarungan yang tidak pernah selesai. Tidak akan pernah habis selama aku masih hidup (Tarian Bumi, p. 43, line 9)

$\mathrm{TL}$ : I see life as a never-ending battle, a war that will continue as long as I live (Earth Dance, p. 40, line 6)

According to Lakoff and Johnson (1980), the SL sentence above could be identified as a structural metaphor which obviously structured the term hidup (life) as the topic into the term of pertarungan (battle) as an image. According to Merriam Webster online dictionary, the word 'battle' was defined as a struggle to succeed or survive. Sometimes, in life, the human must struggle or fight to survive on it. Therefore, 'life' and 'battle' were decided had a point of similarity of having struggle, since there were concepts; 'life is struggle', and 'battle is struggle'.

However, the metaphorical expression in the source language had changed into simile in the target language which was shown by the addition 'as' between the topic and image. The Indonesian metaphorical concept hidup adalah pertarungan was translated into 'life as battle' in TL. Therefore, related to theoretical framework stated by Larson (1998), it was 
concluded that the strategy of translating metaphor into simile was applied in this case.

\section{Metaphor into Non-figurative Language}

Sometimes, the meaning of the metaphors could be translated without keeping the metaphorical imagery (Larson, 1998). The translator might remove the image in the source text for such reasons, like did not share an equivalence meaning in both languages. Based on the investigation of the whole data, it was found that the strategy of translating metaphor into non-figurative language was applied in all types of conceptual metaphor.
The structural and ontological metaphor showed the same occurrence by 9 data found (35\%). Meanwhile, the orientation metaphor showed 8 data (30\%) applied this strategy. The comparison of the percentage of data occurrence had been presented in a pie chart as follows:

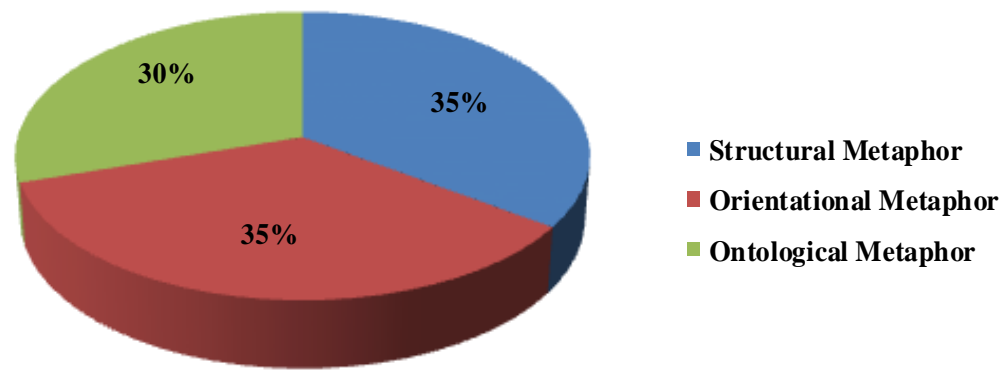

Figure 02. Percentage of the Strategy of Translating Metaphor into Non-figurative Language in Each Type of Conceptual Metaphor

Furthermore, the discussion of the strategy of translating metaphor into non-figurative language in each type of conceptual metaphor had been presented by an example as follows:

Data:

SL: Bayangan Wayan tenggelam saat Telaga merasakan tubuhnya diikat oleh tubuh laki-laki (Tarian Bumi, p. 165, line 22)

TL: This image of Wayan vanished suddenly when Telaga felt herself in the grasp of a man (Earth Dance, $\mathrm{p}$. 136, line 22)

Another type of conceptual metaphor was an orientational metaphor. It was a metaphor that organized a whole system of concepts with respect to another. In other words, orientational metaphor dealt with spatial orientation (Lakoff and Johnson, 1980). In this case, the source sentence above could be identified as an orientational metaphor which was shown by phrase bayangan Wayan tenggelam. The term tenggelam corresponded to the term 'sink' in TL. According to the Merriam Webster online dictionary, 'sink' meant to go to the bottom or go down. It meant, the word tenggelam belonged to Indonesian spatial orientation since the term 'sink' had an association with orientation 'down'. Based on the sentence (SL), the word tenggelam was used to express the disappearance of Telaga's imagination about Wayan. Therefore, it could be said that the sentences in the source language raised the orientational concept 'disappear is down'.

Meanwhile, based on the observation on translation product of that metaphorical concept, the target language seemed to decline the concept 'disappear is down'. It was due to the target sentence did not elaborate any metaphorical sense. The translator preferred to 
translate that phrase bayangan wayan tenggelam into "this image of Wayan vanished suddenly..." which was not a kind of metaphorical expression. Therefore, based on the theoretical framework of translation strategy proposed by Larson (1998), it could be identified that the translator of the novel applied the strategy of translating metaphor into non-figurative language in this case.

\section{The Predominant of Translation Strategies in Each Type of Conceptual Metaphor}

Based on the observation on the number of translation strategy in each type of conceptual metaphor, it was found that there were some tendencies identified in this study. Those tendencies were demonstrated by the comparison between the percentages of each translation strategy based on types of conceptual metaphor. That comparison had been represented in a chart as follows:

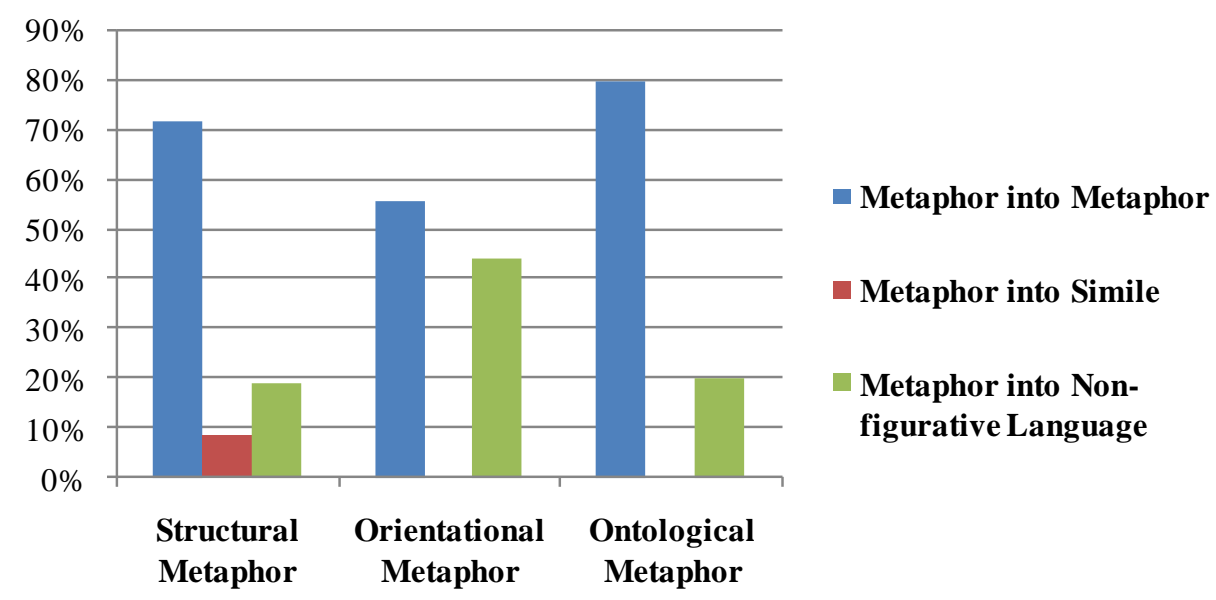

Figure 03. Percentages of Translation Strategies in Each Type of Conceptual Metaphor

Based on the chart above, it was determined that structural metaphor could be translated by all strategies of translation proposed by Larson (1998). This type of conceptual metaphor showed that the most probable strategy that could be applied was the strategy of translating metaphor into metaphor by 33 data (72\%) from 46 total data found. On the other hand, the data also showed that only 9 data (19\%) of structural metaphor was translated non-figuratively. Based on these facts, it could be identified that the concept of both cultures in SL and TL was almost similar since the Indonesian structural metaphors found in Tarian Bumi were mostly translated into metaphor in English. It was quite reasonable since the story mainly narrated the human's life in general. Therefore, the metaphorical concepts such as life is battle, life is a game, life is a gambling and life is drama which dominated the concept in both Indonesian and English structural metaphor seemed to become the universal concepts for the people in the entire world.

Another type of conceptual metaphor, orientational metaphor, seemed more difficult to be translated literally since the data showed that the most dominant strategy applied in this case was metaphor that was translated into non-figurative language by 9 data found (56\%). The rest was the strategy of translating metaphor into metaphor by 7 data found $(44 \%)$, meanwhile, there was no data found in the strategy of translating metaphor into simile. Based on these facts, there was no significant difference number of translation strategies between the metaphor which was translated into metaphor and metaphor which was 
translated into non-figurative language since the data was showing the balance number $(56 \%$ and 44\%). Hence, the translator seemed to translate the metaphorical sense especially orientational metaphor in SL into TL carefully so their translation products could be accepted accurately and naturally by the readers in TL. Meanwhile, based on the data found, the strategy of translating metaphor into simile seemed cannot be applied in this type of conceptual metaphor which occurred in the novel. Contradictory to the structural metaphor, orientational metaphor in every language preferred to use the specific concept. For instance, the novel Tarian Bumi consisted of Indonesian orientational metaphor which mostly had concept disappear is down; appear is up (it shown by the term tenggelam which occurred frequently in the source text), meanwhile in TL culture, the concept for 'appear' and 'disappear' preferred to use the concept appear is out; disappear is in. Therefore, many source texts could not be translated into the same sense since both of SL and TL had a different concept about 'appear' and 'disappear' in association with spatial orientation. Moreover, that condition was supported by the theoretical framework proposed by Lakoff and Johnson (1980) who stated that metaphorical orientations were not arbitrary so they could vary from culture to culture. In other words, the translator had to make a consideration to translate them into the literal language.

On the other hand, the ontological metaphor was the most probably type that could be translated into the same figurative sense since the analysis showed 32 data (80\%) of ontological metaphors found in the Tarian Bumi were translated into metaphors in Earth Dance. Similarly to the orientational metaphor, there was no data found in the strategy of translating metaphor into simile in this type. Meanwhile, 4 data (20\%) of ontological metaphor were translated non-figuratively. Based on these facts, it could be identified that the concept of personification and metonymy (ontological metaphor) in both cultures of SL and TL were almost similar. Therefore, the translator seemed does not have many obstacles in translating the metaphorical concepts especially ontological metaphors in SL into TL.

\section{CONCLUSION AND SUGGESTION}

After presenting the data analysis, it could be concluded that there were 102 Indonesian conceptual metaphors found in the novel Tarian Bumi. Based on the observation, the most dominant Indonesian conceptual metaphor occurred in the novel was structural metaphor by 46 data found (or $45 \%$ ), followed by ontological metaphor by 40 data found (or $39 \%)$, and orientational metaphor by 16 data found (or 16\%). Meanwhile, according to the observation on the translation strategy, it was found that the strategy of metaphor which was translated into metaphor dominated the strategy by 72 data found (or $71 \%$ ). Then, the second dominant strategy was metaphor translated into non-figurative language by 26 data found (or 25\%) and followed by the strategy of translating metaphor into simile by 4 data found (or 3.9\%). Based on this fact, the conceptual metaphor had a big possibility of translating their metaphorical concepts in SL into the same sense in TL. It was shown by the number of translation strategy which was applied in Tarian Bumi into Earth Dance was dominated by the strategy of metaphor translated into metaphor.

Related to the conclusion of the study, it was identified that the metaphor in SL was mostly translated into metaphor in TL. It indicated that there were no significant differences between the conceptual metaphor in Indonesian and English. Therefore, the researcher suggested to the students especially in English literature to be brave in translating the text, especially conceptual metaphor. As stated previously in this study, conceptual metaphor had an association with the human thought in common or general. Therefore, every concept in each language must have a similarity. Since the concept of translation was transferring a meaning in SL into TL and the receptor could understand the meaning, there was no more fear to translate any kind of texts. 


\section{REFERENCES}

Bull, Victora (ed). (2008). Oxford learner's pocket dictionary. Oxford University Press: China.

Catford, J.C. (1965). A linguistic theory of translation. London: Oxford University Press.

Chen, H., Qiu, R., \& Wang, Y. (2014). The Translation Strategy of Advertisement Based on Nonequivalence between Chinese and English Conceptual Metaphors. International Journal of English Linguistics, Vol. 3 No. 5, 29-37. Retrieved June 27, 2017, from http://www.ccsenet.org/

Eagleton, Terry. 2005. The English novel: An introduction. Malden: Blackwell Publishing.

Fadaee, Elaheh. (2011). Translation Technique of Figure of Speech: A Case Study of George Orwell's '1984 and Animal Farm'. Journal of English and Literature, Vol. 2(8), pp. 174-181. Retrieved November 27, 2016, from http://www.academicjournals.org/.

Lakoff, G., \& Johnson, M. 1980. Metaphor we life by. Chicago and London: The University of Chicago Press.

Larson, Mildred L. (1998). Meaning-based translation. New York: University Press of America.

Madsar, S. A. 2010. The Analysis of the Translation of Metaphorical Expressions in the Novel 'The God of Small Things' by Arundhati Roy into 'Yang Maha Kecil' by A. Rahartati Bambang Haryo. Unpublished Thesis. Surakarta: Sebelas Maret University.

Merriam Webster (n.d). Definition of battle. Retrieved May, 31, 2017, from http://www.merriamwebster.com/dictionary/battle
Merriam Webster (n.d). Definition of sink. Retrieved May, 31, 2017, from http://www.merriamwebster.com/dictionary/sink

Rusmini, Oka. (2007). Tarian bumi. Jakarta: PT Gramedia Pustaka Utama.

Rusmini, Oka. (2011). Earth dance. (Rani Amboyo and Thomas M. Hunter, Trans.) Jakarta: The Lontar Foundation. 